University of Rhode Island

DigitalCommons@URI

Open Access Master's Theses

2017

\title{
Effect of a Nutritiion Intervention on Fruit and Vegetable Intake in Elementary School Students
}

Jennifer L. Goodwin

University of Rhode Island, jlgoodwin@my.uri.edu

Follow this and additional works at: https://digitalcommons.uri.edu/theses

\section{Recommended Citation}

Goodwin, Jennifer L., "Effect of a Nutritiion Intervention on Fruit and Vegetable Intake in Elementary School Students" (2017). Open Access Master's Theses. Paper 1021.

https://digitalcommons.uri.edu/theses/1021

This Thesis is brought to you for free and open access by DigitalCommons@URI. It has been accepted for inclusion in Open Access Master's Theses by an authorized administrator of DigitalCommons@URI. For more information, please contact digitalcommons-group@uri.edu. 
EFFECT OF A NUTRITION INTERVENTION ON FRUIT

AND VEGETABLE INTAKE IN ELEMENTARY SCHOOL STUDENTS

BY

JENNIFER L. GOODWIN

A THESIS SUBMITTED IN PARTIAL FULFILLMENT OF THE

REQUIREMENTS FOR THE DEGREE OF

MASTER OF SCIENCE

IN

NUTRITION AND FOOD SCIENCE

UNIVERSITY OF RHODE ISLAND

2017 
MASTER OF SCIENCE

OF

JENNIFER L. GOODWIN

APPROVED:

Thesis Committee:

Major Professor Geoffrey W. Greene

Linda Sebelia

Alison Tovar

Adam Moore

Nasser H. Zawia

DEAN OF THE GRADUATE SCHOOL

UNIVERSITY OF RHODE ISLAND

2017 


\begin{abstract}
Objective: To evaluate the effectiveness of a 10-week Policy, Systems, and Environment (PSE) nutrition education curriculum to increase fruit and vegetable (FV) intake, PSE and FV knowledge, and improvement in attitudes towards FV. Design: Quasi -experimental design.
\end{abstract}

Participants/Setting: $\mathrm{N}=312$ (intervention=142, comparison $=170$ ) $5^{\text {th }}$ grade students in low-income, urban elementary schools in Pawtucket, RI selected by established working relationship between project committee members and teachers in the Pawtucket School District.

Intervention: Both groups participated in the Fresh Fruit and Vegetable Program. Intervention schools received an additional 10-week PSE education curriculum. Both groups completed pre and post-surveys.

Main Outcome Measures: Self-reported dietary intake of fruits and vegetables, knowledge of PSE and FV, and attitudes towards FV.

Analyses: Independent t-tests, paired sample t-tests, analysis of variance, analysis of covariance.

Results: There were no significant differences in FV consumption from baseline to follow-up between or within groups. Controlling for differences at baseline, the intervention group had significantly higher PSE knowledge $(\mathrm{p}<.001)$, FV knowledge $(\mathrm{p}<.05)$, and attitudes towards FV $(\mathrm{p}<.05)$ at follow-up than the comparison group.

Conclusions and Implications: This PSE intervention had a positive impact on knowledge and attitudes, but not behavior. PSE interventions have the potential to 
empower students to voice their opinions about the types of food they are served at school and home. 


\section{ACKNOWLEDGMENTS}

First and foremost, I would like to thank my committee members - Dr. Geoffrey Greene, Linda Sebelia, Dr. Alison Tovar and Dr. Adam Moore - for their guidance and support throughout this process. I must give special thanks to Dr. Greene for always making time to meet with me, reading numerous drafts of proposals, manuscripts and literature reviews, and for endless patience to match endless questions; and Linda for providing me with the invaluable opportunity to work at SNAP-Ed and complete my thesis in the area of nutrition I love most, community. Thank you to the SNAP-Ed and EFNEP staff for their support and participation in this project, especially the EFNEP community nutrition assistants and Katie Mulligan.

I cannot forget my family: to my parents and brother, there are many miles between us, but I know you are only a phone call away and I appreciate all your support; to my partner, Brian, for enduring the stress and anxiety, and continuing to stand by my side; and to my son, Bryce, who sacrificed the most but always gives the best hugs - I love you. 


\section{PREFACE}

This thesis was prepared in manuscript format following the author guidelines for

The Journal of Nutrition Education and Behavior. After submitting this thesis, the manuscript may be submitted for publication. 


\section{TABLE OF CONTENTS}

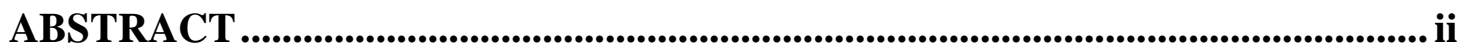

ACKNOWLEDGMENTS ............................................................................................. iv

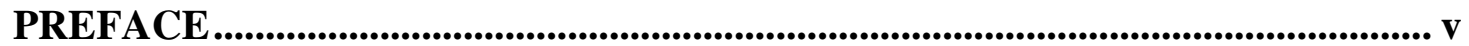

TABLE OF CONTENTS....................................................................................................... vi

LIST OF TABLES ..................................................................................................................... vii

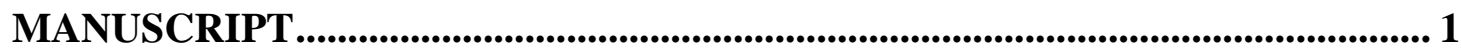

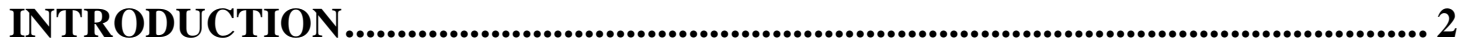

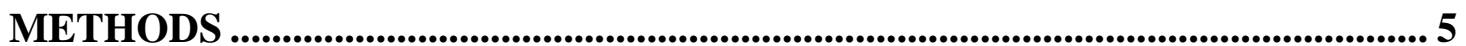

RESULTS ............................................................................................................................... 9

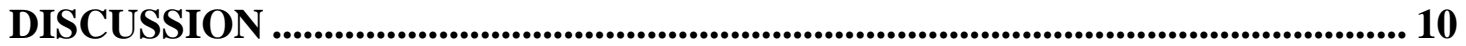

IMPLICATIONS FOR RESEARCH AND PRACTICE .......................................... 13

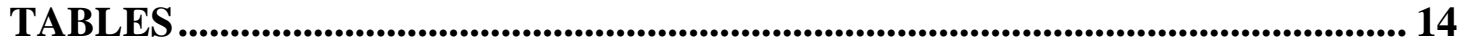

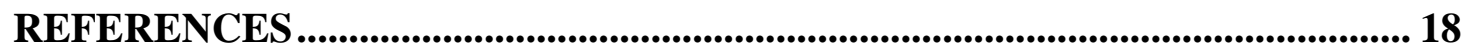

APPENDICES ….................................................................................................................... 22

A. LITERATURE REVIEW .................................................................. 22

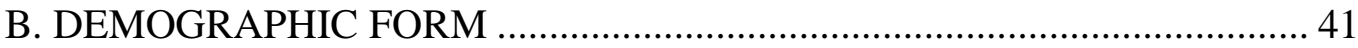

C. SNAP-ED FRUIT AND VEGETABLE CHECKLIST .................................. 42

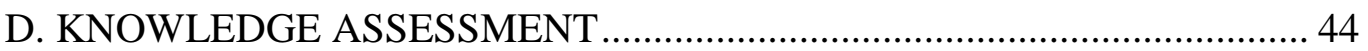




\section{LIST OF TABLES}

TABLE

PAGE

Table 1. Description of Policy, Systems and Environment (PSE) Lessons for PSE

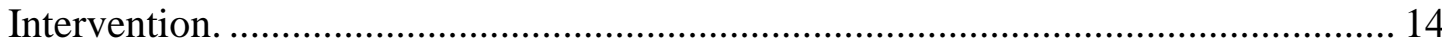

Table 2. Study Sample Demographics of Fifth Grade Students in Four Schools in

Pawtucket, Rhode Island School District.............................................................. 15

Table 3. Change in Student's Response to Number of Times They Ate Fruits and

Vegetables Yesterday from Pre to Post-Intervention............................................... 16

Table 4. Change in Student's Knowledge and Attitudes from Pre to Post-Intervention 
MANUSCRIPT

"Effect of a Nutrition Intervention on Fruit and Vegetable Intake in Elementary

School Students"

By

Jennifer Goodwin ${ }^{1}$

Geoffrey Greene PhD, RD, LDN $^{2}$

Linda Sebelia MA, MS, RD, LDN

Alison Tovar PhD, MPH ${ }^{4}$

Adam Moore PhD ${ }^{5}$

Prepared for submission to the Journal of Nutrition Education and Behavior

${ }^{1}$ Department of Nutrition and Food Sciences, Fogarty Hall, University of Rhode Island, Kingston RI 02881 (jlgoodwin@my.uri.edu)

${ }^{2}$ Department of Nutrition and Food Sciences, Fogarty Hall, University of Rhode Island, Kingston RI 02881 (gwg@uri.edu)

${ }^{3}$ Department of Nutrition and Food Sciences, Fogarty Hall, University of Rhode Island, Kingston RI 02881 (sebelia@uri.edu)

${ }^{4}$ Department of Nutrition and Food Sciences, Fogarty Hall, University of Rhode Island, Kingston RI 02881 (alison_tovar@uri.edu)

${ }^{5}$ School of Education, Chafee Hall, University of Rhode Island, Kingston RI 02881 (adam_moore@uri.edu) 


\section{INTRODUCTION}

\section{Importance of Fruit and Vegetable Consumption}

According to recent data, children in the United States are not meeting the recommended dietary intakes for fruits and vegetables $(\mathrm{FV})^{1}$. Males age 9 to 13 years are consuming an average of 1.1 cups of vegetables per day compared to the recommended 2 to 3 cups per day, and an average of 1.1 cups of fruit per day compared to the recommended 1.5 to 2 cups per day ${ }^{1}$. Females age 9 to 13 years are consuming an average of 1 cup of vegetables per day compared to the recommended 1.5 to 3 cups per day, and an average of 1.1 cups of fruit per day compared to the recommended 1.5 to 2 cups per day ${ }^{1}$.

Epidemiologic studies have shown a positive association between increased FV intake and a decrease in the long-term risk of obesity ${ }^{2}$. This is of importance given that $17.7 \%$ of children age 6 to 11 years are obese ${ }^{3}$. Obese children are more likely to be obese as adults putting them at risk for several obesity-related complications including diabetes, heart disease, and some cancers ${ }^{4}$.

\section{Nutrition Interventions in Schools}

Nutrition education is a powerful way to increase a child's nutrition knowledge, and an increase in nutrition knowledge can lead to healthier food choices ${ }^{5-7}$. Many studies go beyond looking at just an increase in knowledge or the ability to make a healthier choice, and measure changes in consumption of healthy foods ${ }^{5,8-20}$.

The Fresh Fruit and Vegetable Program (FFVP), federally funded by the United States Department of Agriculture, is offered by more than $25 \%$ of elementary schools in the 
US ${ }^{13,21}$. The program is designed to provide an additional serving of FV to children in low-income elementary schools as a snack independent from school breakfast or lunch ${ }^{13,21}$. An evaluation estimating the effect of the FFVP showed that students in schools who participate in the FFVP increased FV intake by approximately one third of a cup (0.32 cups per day; $p<0.001)$ more than students at schools who did not participate in the FFVP ${ }^{21}$. Furthermore, one study of 3 low-income, urban elementary schools showed that the addition of an education component to the FFVP also increases consumption of $\mathrm{FV}^{20}$.

The Academy of Nutrition and Dietetics 20113 position paper, cited school-based nutrition education interventions as more effective when paired with other components such as physical activity and supplemented with FV offerings ${ }^{11}$. Furthermore, this paper indicated that school-based nutrition interventions in general were most successful when they included policy change, input from multiple parties (students, parents, school staff), and environmental change ${ }^{11}$.

School-based nutrition interventions have turned their focus to Policy, Systems and Environmental (PSE) approaches to combat childhood obesity ${ }^{22}$. Policy establishes rules that influence daily decisions, such as the federal government increasing the amount of FV required to be served at school lunch ${ }^{23}$. Systems influence how these policies are carried out, such as adding a larger variety of FV to the school lunch menu to meet federally mandated guidelines ${ }^{23}$. Environment is a change to the physical environment ${ }^{23}$. A change to the environment would be adding a garden cart to the school lunchroom to display the increased variety of FV. PSE interventions can empower children to be involved in changes that impact them directly, making them 
more likely to incorporate these changes into their daily routines ${ }^{11,24}$. A 2012 review of studies on student involvement suggests that empowering students by involving them in the decision making process has a strong positive effect on their self-esteem and ability to drive change ${ }^{25}$. Empowerment gives children a voice and can include involvement in activities such as learning constructive ways to participate in Wellness Committee meetings, or making suggestions for ways to improve the school cafeteria environment ${ }^{11,24}$.

The Shaping Healthy Choices Program is a PSE intervention designed for fourth grade students in California elementary schools ${ }^{8,26}$. The main objectives of the program were to increase nutrition knowledge, increase FV intake, increase vegetable preference, and improve BMI percentiles ${ }^{8,26}$. The intervention involved implementation of school gardens; participation of family, community and wellness committee members; local produce featured in school lunchrooms; cooking demonstrations; and 15 1-hour nutrition education lessons being taught in the classrooms by a trained nutrition educator ${ }^{8,26}$. Results showed that students in the intervention schools had significant improvement in BMI percentiles $(-6.08 ; \mathrm{p}<.01)$, BMI Z-scores $(-.28 ; \mathrm{p}<.001)$, and waist to height ratio $(-.02 ; \mathrm{p}<.001)^{8}$. There was also a significant increase in nutrition knowledge when compared to the control schools $(\mathrm{p}<.001)$, but there were no changes in FV intake or vegetable preference ${ }^{8}$.

There are a limited number of studies measuring the impact of a PSE intervention on FV intake in elementary school students ${ }^{7,8,27,28}$. The primary purpose of this study was to determine if there would be an increase in FV intake in elementary school students following a PSE intervention. Additional purposes were to determine if there would 
be an increase in PSE and FV knowledge, and attitudes towards FV of elementary school students following a PSE intervention.

\section{METHODS}

\section{Design}

This study was part of the University of Rhode Island Community Nutrition Education Program "Empowering Urban School Children to Increase Fruit and Vegetable Consumption Through EFNEP-Enhanced PSE Interventions". The design of the study was quasi-experimental. Four schools from an ethnically and racially diverse city were chosen by the Project Advisory Committee - the Supplemental Nutrition Assistance Program Education (SNAP-Ed) director and School Wellness Advisor. The Committee assigned two schools to the intervention group and two schools to the comparison group based on working relationships with the schools. All four schools participated in the FFVP, and all four schools were supposed to receive eight SNAPEd lessons during the school year to enhance the FFVP. The intervention schools received an additional PSE education component while comparison schools did not. The intervention and comparison schools were assessed at baseline (October 2015) and follow-up (April 2016). It was hypothesized that students in the intervention group would increase FV intake more than students in the comparison group, that PSE and FV knowledge would increase in intervention schools more than comparison schools, and that students in the intervention group would have a greater change in attitude toward FV than the comparison group. 


\section{Subjects}

This study involved fifth grade students in 4 urban elementary schools in Pawtucket, RI. The intervention group included 6 classrooms in 2 schools $(n=142)$. The control group also included 6 classrooms in 2 schools $(n=170)$. Pawtucket is located on the northern border of Providence, RI. The population of Pawtucket is estimated at 71,499 with $66.5 \%$ of people identifying as white, $13.4 \%$ as African American, and $19.7 \%$ as Hispanic or Latino ${ }^{29}$. Demographic information for students enrolled in Pawtucket public schools in 2015 included, 35\% identified as white, 31\% Hispanic, and $26 \%$ African American ${ }^{30}$. The Rhode Island Department of Education's Community Eligibility Provision allows schools in high poverty areas to offer free lunch to all children enrolled in those schools; Pawtucket Schools meet the qualification for this allowance with $76 \%$ of students being identified as low-income 30,31 .

\section{Intervention}

Students in both the intervention and comparison schools participated in the FFVP, and were expected to also participate in the FFVP education program. The intervention schools received an additional nutrition education intervention of 10 PSE lessons, proposed as being taught every other week for a period of 20 minutes by the Expanded Food and Nutrition Education Program community nutrition assistants.

Lessons were designed to empower fifth grade students to change their school environment and improve FV intake by participating in several different activities from October 2015 to March 2016. In the first two lessons, students learned how to write a letter to the Wellness Committee to communicate the types of FV they enjoy 
and would like to see served at school. The following lessons focused on students learning to conduct interviews and they were asked to interview their parents to obtain recipes that included FV. Students were instructed to bring their recipes to school where they decided on their favorite recipe within each class. The entire fifth grade at each school had the opportunity to taste test the favorite recipes for each class in that school and decide on one favorite recipe. Lessons then focused on media and advertising; students created posters to advertise a school-wide taste-testing of the winning recipe to be held during school lunch at each school. On the day of the taste testing, fifth grade students encouraged all other students to try the recipe and vote whether they would eat it again or not. (See Table 1 for a more detailed description of each lesson.) Letters were written by the EFNEP director, to the Wellness Committee, at the beginning of the year to describe the intervention and at the end of the year to provide results. Students and parents were also encouraged to attend Wellness Committee meetings, and parents received newsletters throughout the intervention to inform them about the program activities.

\section{Instruments}

Student demographic information. Student demographics were collected at baseline using the SNAP-Ed - Child/Youth Participant Survey Form (see Appendix B). The form includes items assessing age, attendance at URI SNAP-Ed workshops in the last year, gender, language spoken at home (to determine ethnicity), and race.

Measurement of FV consumption. FV consumption was measured in both groups pre and post-test using the SNAP-Ed Fruit and Vegetable Checklist (see Appendix C) to assess number of times fruit was consumed yesterday and number of times 
vegetables were consumed yesterday with 6 response options ranging from 0 to 5 or more times. The Fruit and Vegetable Checklist has not been validated.

Measurement of PSE and FV knowledge and attitudes towards FV. All students completed pre and post knowledge assessments (see Appendix D) to evaluate change in PSE knowledge as well as change in knowledge of FV and attitudes towards FV served at school and home. The instrument has four parts: part 1 and 2 assess FV knowledge, part 3 assesses PSE knowledge, and part 4 assesses attitudes towards FV. All items on the first 3 parts of the knowledge assessment were scored as $1=$ correct and $0=$ incorrect or missing. Part 1 asks 4 questions in a multiple-choice format about which foods are considered FV and the quantities that should be consumed each day with a scoring range of 0 (all incorrect) to 4 (all correct); part 2 asks students to match 5 colors of FV with the affected part of the body with a scoring range of 0 (all incorrect) to 5 (all correct); part 3 asks 7 items about PSE in a multiple-choice format with a scoring range of 0 (all incorrect) to 7 (all correct); part 4 asks 6 questions about student's feelings about the FV offered at school lunch and at home with a scoring range of 1 (no) to 3 (yes) for the first 4 questions, and scoring range of 1 ("I don't eat fruits and vegetables") to 6 ("I like them a lot") for the last 2 questions. The PSE knowledge assessment has been evaluated by the nutrition educators at SNAP-Ed who determined it has face validity.

\section{Analyses}

All data were analyzed using the statistical software program, SPSS version 22.0, IBM Corp., Armonk, NY. Differences in demographic information were analyzed using independent sample t-tests. 
FV variables were normally distributed and there were no differences in FV consumption at baseline. Accordingly, between group change in FV consumption was analyzed using an ANOVA.

At baseline, the intervention group scored significantly higher on the PSE knowledge assessment than the comparison group $(t=3.22, \mathrm{p}<.001)$. The intervention group also scored significantly higher than the comparison group on FV knowledge at baseline $(t=2.71, \mathrm{p}<.01)$, and attitudes towards FV at baseline $(t=3.04, \mathrm{p}<.01)$. Accordingly, between group change in PSE knowledge, FV knowledge and attitudes towards FV were also analyzed using ANCOVAs with the baseline value as a covariate. Within group differences for FV intake, PSE knowledge, FV knowledge, and attitudes towards FV were measured using paired t-tests.

\section{RESULTS}

There were no significant differences between groups by age (average age $10.19 \pm$ .45), gender (55\% male), or ethnicity (Hispanic or Non-Hispanic defined by students reporting whether or not they speak Spanish at home; 39\% Hispanic from intervention schools, 61\% Hispanic from comparison schools) (Table 2).

There were no significant changes in FV consumption between groups from pre to post-intervention (Table 3). There were also no significant changes in FV consumption within groups from pre to post-intervention (Table 3).

The intervention group scored significantly higher on the post PSE knowledge assessment than the comparison group when adjusted for baseline score in an ANCOVA $(\mathrm{F}=37.56, \mathrm{p}<.001)$ (Table 4). There was also a significant increase in score 
on the PSE knowledge assessment from pre to post-test in both the intervention group $(t=-6.55, \mathrm{p}<.001)$ and the comparison group $(t=-2.30, \mathrm{p}<.05)($ Table 4$)$.

The intervention group scored significantly higher on the post FV knowledge assessment than the comparison group when adjusted for baseline score in an ANCOVA $(\mathrm{F}=3.94, \mathrm{p}<.05)$ (Table 4). Analysis of within group change showed that only the comparison group had a significant increase in FV knowledge from pre to post-test on the FV knowledge assessment $(t=-2.03, \mathrm{p}<.05)$ (Table 4).

The intervention group scored significantly higher on the post FV attitude assessment than the comparison group when adjusted for baseline score in an ANCOVA ( $\mathrm{F}=5.86$, $\mathrm{p}<.05)$ (Table 4). Analysis of within group change showed that only the comparison group had a significant increase in attitudes towards FV from pre to post-test on the FV attitude assessment $(t=2.17, \mathrm{p}<.05)($ Table 4$)$.

\section{DISCUSSION}

While many studies have evaluated the efficacy of PSE interventions on dietary outcomes, nutrition-related knowledge, and attitudes, few have looked at urban fifth grade students ${ }^{9,12,13,28-35}$. Successful studies used several strategies to employ change including involvement of parents and Wellness Committees and a structured nutrition education program ${ }^{8,27,33,35,37,38}$. What sets this study of urban fifth grade students apart from other interventions is the use of student empowerment to drive change.

Other elementary school-based PSE interventions have found significant decreases in unhealthy food items being brought to school form the outside, increases in nutrition knowledge, and improved attitudes towards healthy foods ${ }^{8,27,28}$. However, this study 
found no change in intake of FV. Nevertheless, this study found significant improvements in knowledge and attitudes.

Although there were no statistically significant demographic differences between groups, $61 \%$ of students in the comparison group identified their language spoken at home as Spanish, compared to only $39 \%$ in the intervention group. National data indicates Hispanic students, on average, score lower than Non-Hispanic students at reading, which may explain why the intervention group scored significantly higher on the knowledge assessment at baseline than the comparison group ${ }^{39}$. Comprehension of the knowledge assessment may have been further complicated by the fact that the assessment was not validated and the assessments were provided in English only, which may not have been appropriate for Spanish speaking students.

Studies aimed at increasing FV intake typically see an increase around 1/3 cup per day, compared to this study which found no significant change in FV intake ${ }^{11}$. Most other studies use a multi-item food frequency questionnaire to measure dietary intake, such as The Block Food Frequency Questionnaire used in Shaping Healthy Choices, and these food frequency questionnaires may be more accurate than the two-item instrument used in this study ${ }^{8,11,26}$. During administration of the assessment, educators read each question out loud for the students, clearly explaining the directions, but students often worked ahead disregarding the directions. Additionally, in some classrooms, the FV assessment was administered on a Monday, so students were reporting FV consumption for a weekend day which can vary greatly from FV consumption during the week. 
The significant increase in PSE and FV knowledge is consistent with other studies who have assessed changes in knowledge following interventions which incorporate an education component ${ }^{5,8,11}$. To our knowledge, this is the first study of its kind to evaluate a change in PSE knowledge. These results are encouraging, but further research is necessary to determine whether students understand the concept of PSE. Additionally, results from the FV knowledge assessment do not reflect the intended design because the FFVP education lessons were not delivered as intended in both the intervention and control schools. A survey of health teachers at all four schools indicated that in the intervention group 5 of the 8 FFVP education lessons were taught at one school, and 1of the 8 lessons were taught at the other school; in the comparison group, 3 of the 8 lessons were taught at one school and 6 of the 8 lessons were taught at the other school.

The significant improvement in attitudes towards FV is consistent with Campbell, et al., who found significant improvement in attitudes towards healthy eating using a validated survey ${ }^{28}$. The improvement in attitudes associated with this study were supported by focus groups conducted with students post-intervention, which revealed that they felt empowered by being involved in the decision-making process ${ }^{40}$. The majority of students in both intervention schools voted "yes", they would eat the recipe again, and the recipes (apple cucumber salad, and roasted carrots) were added to the cycle lunch menu. Empowering students has been shown to improve self-esteem and increase the likelihood that they will participate in a meaningful way where they share their voice ${ }^{25}$. Future research, using a validated attitude survey is needed. 


\section{Strengths and Limitations}

A strength of this study is that, to the author's knowledge, it is the first PSE nutrition intervention with elementary school students that focuses on empowering students, and uses that empowerment to drive change. There were several limitations though. Dietary assessments with children are challenging and the accuracy is questionable ${ }^{41}$. The Fruit and Vegetable Checklist that was used in this study may not be a sensitive instrument to assess change. Although significant differences in baseline score were statistically controlled for using ANCOVA, future research should focus on schools being more evenly matched by student demographics. Additional demographics, such as race, would have been useful, but the instrument used to collect this information was poorly understood by students. Schools in this study were not randomly selected, and including more schools would have provided a larger sample with the potential for more robust results.

\section{IMPLICATIONS FOR RESEARCH AND PRACTICE}

This study was associated with improved knowledge and attitudes, however, there was no difference in FV intake. Focusing on student empowerment may lead to longer term changes. Future research needs more sensitive tools, but this intervention focusing on empowerment is promising. This study served as a pilot study to be replicated and built upon. SNAP-Ed has revised the program and is delivering it in the Providence, RI school district as, "Students Take Charge", but has embraced the same focus on empowering students to drive change through PSE related activities. 
TABLE 1: Description of Policy, Systems and Environment (PSE) Lessons for PSE Intervention

\begin{tabular}{|l|l|}
\hline PSE Lesson & Description \\
\hline $\begin{array}{l}\text { Lesson 1 - Fruits and } \\
\text { Vegetables You Enjoy }\end{array}$ & $\begin{array}{l}\text { Students discuss FV they enjoy and draft a letter to the } \\
\text { wellness committee about adding these FV to the lunch } \\
\text { menu }\end{array}$ \\
\hline $\begin{array}{l}\text { Lesson 2 - } \\
\text { Overcoming Barriers }\end{array}$ & $\begin{array}{l}\text { Students discuss barriers to eating FV and how to } \\
\text { communicate this with the wellness committee }\end{array}$ \\
\hline $\begin{array}{l}\text { Lesson 3 - Let's Read } \\
\text { a Recipe! }\end{array}$ & $\begin{array}{l}\text { Students learn about all the different components of a } \\
\text { recipe }\end{array}$ \\
\hline $\begin{array}{l}\text { Lesson } 4-\text { It's Time } \\
\text { to Role-play! }\end{array}$ & $\begin{array}{l}\text { Students learn how to interview their parents about a FV- } \\
\text { based recipe they eat at home }\end{array}$ \\
\hline $\begin{array}{l}\text { Lesson 5 - Making } \\
\text { Requests }\end{array}$ & $\begin{array}{l}\text { Students learn a constructive way to tell their parents } \\
\text { which FV they like best }\end{array}$ \\
\hline $\begin{array}{l}\text { Lesson 6- Taste } \\
\text { Testing }\end{array}$ & $\begin{array}{l}\text { Students taste test recipes and vote on the one they like } \\
\text { best }\end{array}$ \\
\hline $\begin{array}{l}\text { Lesson 7 - Media and } \\
\text { Food Ads }\end{array}$ & Students learn about advertising and slogans \\
\hline $\begin{array}{l}\text { Lesson 8 - } \\
\text { Advertisements }\end{array}$ & $\begin{array}{l}\text { Students create slogans and brainstorm ideas for posters } \\
\text { to advertise their recipe }\end{array}$ \\
\hline $\begin{array}{l}\text { Lesson 9 - Persuasive } \\
\text { Messages }\end{array}$ & $\begin{array}{l}\text { Students brainstorm ideas for persuasive messages to } \\
\text { promote their recipe during morning announcements }\end{array}$ \\
\hline $\begin{array}{l}\text { Lesson 10 - Taking a } \\
\text { Poll }\end{array}$ & $\begin{array}{l}\text { Students learn how to poll the rest of the student body } \\
\text { about whether they like the new recipe }\end{array}$ \\
\hline
\end{tabular}


TABLE 2: Study Sample Demographics of Fifth Grade Students in Four Schools in Pawtucket, Rhode Island School District

\begin{tabular}{|c|c|c|c|c|}
\hline $\begin{array}{l}\text { Continuous } \\
\text { Variables }\end{array}$ & $\begin{array}{c}\text { Intervention } \\
(\mathrm{Mean} \pm \mathrm{SD}) \\
(\mathrm{n}=142)^{\mathrm{a}}\end{array}$ & $\begin{array}{c}\text { Comparison } \\
(M e a n \pm S D) \\
(n=170)^{\mathrm{a}} \\
\end{array}$ & $\begin{array}{c}\text { Total } \\
(\mathrm{Mean} \pm \mathrm{SD}) \\
(\mathrm{N}=312)^{\mathrm{a}}\end{array}$ & $t$ \\
\hline Age (y) & $10.16 \pm .44$ & $10.22 \pm .45$ & $10.19 \pm .45$ & -1.02 \\
\hline $\begin{array}{l}\text { Baseline } \\
\text { Fruit }^{\mathbf{b}}\end{array}$ & $2.38 \pm 1.45$ & $2.40 \pm 1.53$ & $2.40 \pm 1.49$ & -.121 \\
\hline $\begin{array}{l}\text { Baseline } \\
\text { Vegetables }^{\text {b }}\end{array}$ & $1.86 \pm 1.38$ & $2.01 \pm 1.43$ & $1.94 \pm 1.40$ & -.926 \\
\hline $\begin{array}{l}\text { Baseline PSE } \\
\text { Knowledge }^{\text {b }}\end{array}$ & $3.85 \pm 1.66$ & $3.24 \pm 1.67$ & $3.52 \pm 1.69$ & $3.22 * * *$ \\
\hline $\begin{array}{l}\text { Baseline FV } \\
\text { Knowledge }^{b}\end{array}$ & $4.21 \pm 1.59$ & $3.70 \pm 1.70$ & $3.94 \pm 1.67$ & $2.71 * *$ \\
\hline $\begin{array}{l}\text { Baseline } \\
\text { FVattitudes }\end{array}$ & $19.79 \pm 2.77$ & $18.76 \pm 3.02$ & $19.25 \pm 2.94$ & $3.74 * *$ \\
\hline $\begin{array}{l}\text { Categorical } \\
\text { Variables }\end{array}$ & $\begin{array}{c}\text { Intervention } \\
(\mathrm{n}=142)^{\mathrm{a}}\end{array}$ & $\begin{array}{c}\text { Comparison } \\
(\mathrm{n}=170)^{\mathrm{a}}\end{array}$ & $\begin{array}{c}\text { Total } \\
(\mathrm{N}=312)^{\mathrm{a}}\end{array}$ & $\mathbf{X}^{2}$ \\
\hline \multicolumn{5}{|l|}{ Gender } \\
\hline Male & $71(45 \%)$ & $88(55 \%)$ & $159(100 \%)$ & \\
\hline Female & $68(45 \%)$ & $82(55 \%)$ & $150(100 \%)$ & .001 \\
\hline Total & $139(45 \%)$ & $170(55 \%)$ & $309(100 \%)$ & \\
\hline \multicolumn{5}{|l|}{ Ethnicity } \\
\hline Hispanic & $44(39 \%)$ & $68(61 \%)$ & $112(100 \%)$ & \\
\hline Non-Hispanic & $97(49 \%)$ & $99(51 \%)$ & $196(100 \%)$ & 2.59 \\
\hline Total & $141(49 \%)$ & $167(54 \%)$ & $308(100 \%)$ & \\
\hline
\end{tabular}

a. Not all students responded to every question

b. Baseline values are for number of times fruit was eaten yesterday; number of times vegetables were eaten yesterday; policy, systems and environment knowledge; fruit and vegetable knowledge; attitude towards fruits and vegetables served at school and home

$* \mathbf{p}<.05, * * \mathbf{p}<.01, * * * \mathbf{p}<.001$ 
TABLE 3: Change in Student's Response to Number of Times They Ate Fruits and Vegetables Yesterday from Pre to Post-Intervention

\begin{tabular}{|c|c|c|c|c|}
\hline Variables & $\begin{array}{c}\text { Pre } \\
(\text { Mean } \pm \text { SD })\end{array}$ & $\begin{array}{c}\text { Post } \\
\text { (Mean } \pm \\
\text { SD) }\end{array}$ & $\begin{array}{c}\text { Within } \\
\text { Group } \\
\text { Change } \\
(t)\end{array}$ & $\begin{array}{c}\text { Between } \\
\text { Group } \\
\text { Change } \\
\text { (F) }\end{array}$ \\
\hline \multicolumn{5}{|c|}{ Number of Times I Ate Fruit Yesterday } \\
\hline Intervention $(\mathbf{n}=130)^{\mathrm{a}}$ & $2.34 \pm 1.40$ & $2.26 \pm 1.37$ & .770 & \multirow[b]{2}{*}{.076} \\
\hline Comparison $(n=146)^{a}$ & $2.37 \pm 1.51$ & $2.34 \pm 1.58$ & .189 & \\
\hline \multicolumn{5}{|c|}{ Number of Times I Ate Vegetables Yesterday } \\
\hline Intervention $(\mathbf{n}=138)^{\mathrm{a}}$ & $1.86 \pm 1.38$ & $1.87 \pm 1.46$ & -.136 & \multirow[b]{2}{*}{.070} \\
\hline Comparison $(n=160)^{a}$ & $2.01 \pm 1.43$ & $1.98 \pm 1.59$ & .237 & \\
\hline \multicolumn{5}{|c|}{ Combined Response to Fruits and Vegetables Eaten Yesterday } \\
\hline Intervention $(\mathbf{n}=129)^{\mathrm{a}}$ & $4.21 \pm 2.38$ & $4.16 \pm 2.36$ & .282 & \multirow[b]{2}{*}{.001} \\
\hline Comparison $(n=139)^{a}$ & $4.37 \pm 2.53$ & $4.32 \pm 2.78$ & .226 & \\
\hline
\end{tabular}

a. Not all students responded to every question

$* \mathbf{p}<.05, * * \mathbf{p}<.01, * * * \mathbf{p}<.001$ 
TABLE 4: Change in Student's Knowledge and Attitudes from Pre to PostIntervention

\begin{tabular}{|c|c|c|c|c|c|}
\hline Variables & $\begin{array}{c}\text { Pre } \\
(\text { Mean } \pm \text { SD })\end{array}$ & $\begin{array}{c}\text { Post } \\
(\text { Mean } \pm \text { SD })\end{array}$ & $\begin{array}{c}\text { Within } \\
\text { Group } \\
\text { Change } \\
(t) \\
\end{array}$ & $\begin{array}{c}\text { Adjusted } \\
\text { Post }^{\mathbf{b}} \\
(\text { Mean } \pm \text { SE }) \\
(95 \% \text { CI }) \\
\end{array}$ & $\begin{array}{c}\text { Between Group } \\
\text { Difference in } \\
\text { Adjusted Post } \\
\text { (F) }\end{array}$ \\
\hline \multicolumn{6}{|c|}{ Policy, Systems and Environment Knowledge } \\
\hline $\begin{array}{r}\text { Intervention } \\
(\mathrm{n}=133)^{\mathrm{a}}\end{array}$ & $3.90 \pm 1.66$ & $5.01 \pm 1.57$ & $-6.55 * * *$ & $\begin{array}{l}4.92 \pm .136 \\
(4.66,5.19)\end{array}$ & \\
\hline $\begin{array}{r}\text { Comparison } \\
(n=145)^{\mathrm{a}}\end{array}$ & $3.30 \pm 1.65$ & $3.68 \pm 1.65$ & $-2.30 *$ & $\begin{array}{l}3.76 \pm .130 \\
(3.50,4.02)\end{array}$ & $37.56 * * *$ \\
\hline \multicolumn{6}{|c|}{ Fruit and Vegetable Knowledge } \\
\hline $\begin{array}{r}\text { Intervention } \\
(\mathrm{n}=133)^{\mathrm{a}}\end{array}$ & $4.20 \pm 1.56$ & $4.58 \pm 1.93$ & -1.96 & $\begin{array}{l}4.52 \pm .151 \\
(4.22,4.82)\end{array}$ & \\
\hline $\begin{array}{r}\text { Comparison } \\
(n=145)^{a}\end{array}$ & $3.71 \pm 1.67$ & $4.05 \pm 1.60$ & $-2.03 *$ & $\begin{array}{l}4.10 \pm .144 \\
(3.82,4.39)\end{array}$ & 3.94* \\
\hline \multicolumn{6}{|c|}{ Attitudes Towards Fruits and Vegetables Served at Home and at School } \\
\hline $\begin{array}{r}\text { Intervention } \\
\quad(n=121)^{\mathrm{a}}\end{array}$ & $19.8 \pm 2.77$ & $19.4 \pm 2.57$ & 1.56 & $\begin{array}{l}19.2 \pm .205 \\
(18.8,19.6)\end{array}$ & \\
\hline $\begin{array}{r}\text { Comparison } \\
(n=131)^{a}\end{array}$ & $18.8 \pm 3.02$ & $18.2 \pm 2.62$ & $2.17 *$ & $\begin{array}{l}18.5 \pm .197 \\
(18.1,18.9)\end{array}$ & $5.86^{*}$ \\
\hline
\end{tabular}

a. Not all students responded to every question

b. Adjusted for pre as covariate

$* \mathbf{p}<.05, * * \mathbf{p}<.01, * * * \mathbf{p}<.001$ 


\section{REFERNECES}

1. A Closer Look at Current Intakes and Recommended Shifts - 2015-2020 Dietary Guidelines - health.gov. http://health.gov/dietaryguidelines/2015/guidelines/chapter-2/a-closer-look-atcurrent-intakes-and-recommended-shifts/\#subnav-4. Accessed May 23, 2016.

2. Ledoux TA, Hingle MD, Baranowski T. Relationship of fruit and vegetable intake with adiposity: a systematic review. Obes Rev. 2011;12(5):e143-50. doi:10.1111/j.1467-789X.2010.00786.x.

3. Ogden CL, Carroll MD, Kit BK, Flegal KM. Prevalence of childhood and adult obesity in the United States, 2011-2012. JAMA. 2014;311(8):806-814. doi:10.1001/jama.2014.732.

4. Torpy JM, Campbell A, Glass RM. JAMA patient page. Chronic diseases of children. JAMA. 2010;303(7):682. doi:10.1001/jama.303.7.682.

5. Nguyen B, Murimi M, Rana Z, Lee H, Halloran R. Impact of a Nutrition Education Intervention on Nutrition Knowledge and Dietary Intake of Fruits, Vegetables, and Milk Among Fourth and Fifth-Grade Elementary School Children. J Nutr Educ Behav. 2016;48(7):S79. doi:10.1016/j.jneb.2016.04.211.

6. Watts SO, Piñero DJ, Alter MM, Lancaster KJ. An Assessment of nutrition education in selected counties in New York State elementary schools (kindergarten through fifth grade). J Nutr Educ Behav. 2012;44(6):474-480. doi:10.1016/j.jneb.2012.01.010.

7. Tuuri G, Zanovec M, Silverman L, et al. "Smart Bodies" school wellness program increased children's knowledge of healthy nutrition practices and selfefficacy to consume fruit and vegetables. Appetite. 2009;52(2):445-451. doi:10.1016/j.appet.2008.12.007.

8. Scherr RE, Linnell JD, Dharmar M, et al. A Multicomponent, School-Based Intervention, the Shaping Healthy Choices Program, Improves NutritionRelated Outcomes. J Nutr Educ Behav. 2017. doi:10.1016/j.jneb.2016.12.007.

9. Ritchie LD, Wakimoto P, Woodward-Lopez G, et al. The Healthy Communities Study Nutrition Assessments: Child Diet and the School Nutrition Environment. Am J Prev Med. 2015;49(4):647-652.

doi:10.1016/j.amepre.2015.06.016.

10. Havas S, Heimendinger J, Damron D, et al. 5 A Day for better health--nine community research projects to increase fruit and vegetable consumption. Public Health Rep. 1995;110(1):68-79.

http://www.ncbi.nlm.nih.gov/pubmed/7838947. Accessed February 25, 2017.

11. Hoelscher DM, Kirk S, Ritchie L, Cunningham-Sabo L. Position of the Academy of Nutrition and Dietetics: Interventions for the Prevention and Treatment of Pediatric Overweight and Obesity. J Acad Nutr Diet. 2013;113(10):1375-1394. doi:10.1016/j.jand.2013.08.004.

12. Blom-Hoffman J. School-based promotion of fruit and vegetable consumption in multiculturally diverse, urban schools. Psychol Sch. 2008;45(1):16-27. doi:10.1002/pits.20275.

13. Olsho LEW, Klerman JA, Ritchie L, Wakimoto P, Webb KL, Bartlett S. Increasing Child Fruit and Vegetable Intake: Findings from the US Department of Agriculture Fresh Fruit and Vegetable Program. J Acad Nutr Diet. 
2015;115(8):1283-1290. doi:10.1016/j.jand.2014.12.026.

14. Delgado-Noguera M, Tort S, Martínez-Zapata MJ, Bonfill X. Primary school interventions to promote fruit and vegetable consumption: a systematic review and meta-analysis. Prev Med. 2011;53(1-2):3-9.

doi:10.1016/j.ypmed.2011.04.016.

15. Horne PJ, Tapper K, Lowe CF, Hardman CA, Jackson MC, Woolner J. Increasing children's fruit and vegetable consumption: a peer-modelling and rewards-based intervention. Eur J Clin Nutr. 2004;58(12):1649-1660. doi:10.1038/sj.ejcn.1602024.

16. Song H-J, Grutzmacher S, Munger AL. Project ReFresh: Testing the Efficacy of a School-Based Classroom and Cafeteria Intervention in Elementary School Children. J Sch Health. 2016;86(7):543-551. doi:10.1111/josh.12404.

17. Ransley JK, Taylor EF, Radwan Y, Kitchen MS, Greenwood DC, Cade JE. Does nutrition education in primary schools make a difference to children's fruit and vegetable consumption? Public Health Nutr. 2010;13(11):1898-1904. doi:10.1017/S1368980010000595.

18. Anderson AS, Porteous LEG, Foster E, et al. The impact of a school-based nutrition education intervention on dietary intake and cognitive and attitudinal variables relating to fruits and vegetables. Public Health Nutr. 2005;8(6):650656. http://www.ncbi.nlm.nih.gov/pubmed/16236195. Accessed August 19, 2016.

19. Struempler BJ, Parmer SM, Mastropietro LM, Arsiwalla D, Bubb RR. Changes in fruit and vegetable consumption of third-grade students in body quest: food of the warrior, a 17-class childhood obesity prevention program. J Nutr Educ Behav. 2014;46(4):286-292. doi:10.1016/j.jneb.2014.03.001.

20. Greene GW, Fallon PR, Paolino PP, Sebelia L. Impact of Adding a Nutrition Education Component to the United States Department of Agriculture Fresh Fruit and Vegetable Program on Fruit and Vegetable Consumption in 3rd and 4th Grade Students in an Urban School District. J Acad Nutr Diet. 2015;115(9):A49. doi:10.1016/j.jand.2015.06.170.

21. Gates G, Jackson S, Hildebrand D. Fresh Fruit \& Vegetable Program Participation in Elementary School Influences Fruit and Vegetable Selection in Middle School. J Nutr Educ Behav. 2013;45(4):S30-S31. doi:10.1016/j.jneb.2013.04.083.

22. RNECE-PSE - Policy, Systems, and Environmental Change Center - University of Tennessee. http://snapedpse.org/. Accessed April 14, 2017.

23. Communities Putting Prevention to Work. http://www.cookcountypublichealth.org/files/CPPW/PSE Change.pdf. Accessed April 14, 2017.

24. Story M, Nanney MS, Schwartz MB. Schools and obesity prevention: creating school environments and policies to promote healthy eating and physical activity. Milbank Q. 2009;87(1):71-100. doi:10.1111/j.14680009.2009.00548.x.

25. Mager U, Nowak P. Effects of student participation in decision making at school. A systematic review and synthesis of empirical research. Educ Res Rev. 2012;7(1):38-61. doi:10.1016/j.edurev.2011.11.001. 
26. Scherr RE, Linnell JD, Smith MH, et al. The Shaping Healthy Choices Program: Design and Implementation Methodologies for a Multicomponent, School-Based Nutrition Education Intervention. J Nutr Educ Behav. 2014;46(6):e13-e21. doi:10.1016/j.jneb.2014.08.010.

27. Coleman KJ, Shordon M, Caparosa SL, Pomichowski ME, Dzewaltowski DA. The healthy options for nutrition environments in schools (Healthy ONES) group randomized trial: using implementation models to change nutrition policy and environments in low income schools. Int J Behav Nutr Phys Act. 2012;9:80. doi:10.1186/1479-5868-9-80.

28. Campbell AC, Barnum D, Ryden V, Ishkanian S, Stock S, Chanoine J-P. The Effectiveness of the Implementation of Healthy BuddiesTM, a School-Based, Peer-Led Health Promotion Program in Elementary Schools. Can J Diabetes. 2012;36(4):181-186.e2. doi:10.1016/j.jcjd.2012.07.001.

29. Pawtucket city Rhode Island QuickFacts from the US Census Bureau. http://www.census.gov/quickfacts/table/PST045215/4454640. Accessed April 21, 2016.

30. 2016 Rhode Island KIDS COUNT Factbook.pdf. http://www.rikidscount.org/Portals/0/Uploads/Documents/Factbook 2016/2016 Rhode Island KIDS COUNT Factbook.pdf. Accessed May 21, 2016.

31. National School Lunch Program - Nutrition Programs - RIDE Child Nutrition Programs.

http://www.ride.ri.gov/cnp/NutritionPrograms/NationalSchoolLunchProgram.as px\#2138985-program-data--finance. Accessed May 13, 2016.

32. Campbell AC, Barnum D, Ryden V, Ishkanian S, Stock S, Chanoine J-P. The Effectiveness of the Implementation of Healthy BuddiesTM, a School-Based, Peer-Led Health Promotion Program in Elementary Schools. Can J Diabetes. 2012;36(4):181-186.e2. doi:10.1016/j.jcjd.2012.07.001.

33. Sallis JF, McKenzie TL, Conway TL, et al. Environmental interventions for eating and physical activity. Am J Prev Med. 2003;24(3):209-217. doi:10.1016/S0749-3797(02)00646-3.

34. Kubik MY, Lytle LA, Hannan PJ, Perry CL, Story M. The association of the school food environment with dietary behaviors of young adolescents. Am J Public Health. 2003;93(7):1168-1173.

/pmc/articles/PMC1447928/?report=abstract. Accessed August 19, 2016.

35. Soler RE, Whitten KL, Ottley PG. Communities putting prevention to work: local evaluation of community-based strategies designed to make healthy living easier. Prev Med. 2014;67 Suppl 1:S1-3. doi:10.1016/j.ypmed.2014.08.020.

36. Cradock AL, McHugh A, Mont-Ferguson H, et al. Effect of school district policy change on consumption of sugar-sweetened beverages among high school students, Boston, Massachusetts, 2004-2006. Prev Chronic Dis. 2011;8(4):A74. http://www.pubmedcentral.nih.gov/articlerender.fcgi?artid=3136975\&tool=pmc entrez\&rendertype=abstract. Accessed May 13, 2016.

37. Kern E, Chan NL, Fleming DW, Krieger JW. Declines in student obesity prevalence associated with a prevention initiative - King County, Washington, 2012. MMWR Morb Mortal Wkly Rep. 2014;63(7):155-157. 
http://www.ncbi.nlm.nih.gov/pubmed/24553199. Accessed May 10, 2016.

38. Bunnell R, O’Neil D, Soler R, et al. Fifty communities putting prevention to work: accelerating chronic disease prevention through policy, systems and environmental change. J Community Health. 2012;37(5):1081-1090.

doi:10.1007/s10900-012-9542-3.

39. Rampey BD, Dion GS, Donahue PL. The Nation's Report Card: 2008 Trends in Academic Progress: Executive Summary. US Department of Education, Office of Educational Research and Improvement, National Center for Education Statistics, Washington, DC.

https://nces.ed.gov/nationsreportcard/pubs/main2008/2009479.asp. Published 2009. Accessed March 10, 2017.

40. Lepe S. Process Evaluation of an EFNEP-Enhanced PSE Intervention in Urban Schools [master's thesis]. Kingston: University of Rhode Island; 2017

41. Livingstone MBE, Robson PJ, Wallace JMW. Issues in dietary intake assessment of children and adolescents. Br J Nutr. 2004;92(S2):S213. doi:10.1079/BJN20041169. 


\section{APPENDICES}

\section{A. LITERATURE REVIEW}

\section{Introduction}

Fruit and vegetable (FV) consumption among children is inadequate, averaging only about half of the recommended dietary intake in a population where the obesity rate is $17 \%^{1,2}$. Nutrition education programs have helped increase FV intake, but the effect has been limited (1/3 cup per day). The addition of Policy, Systems and Environmental (PSE) interventions designed to empower fifth grade students to change their environment through policy, could increase the effect ${ }^{3-16}$.

This literature review will discuss the importance of nutrition education interventions for increasing FV intake among elementary school students. Additionally, it will discuss the significance of PSE interventions.

\section{Childhood Obesity}

According to data provided by the 2011-2012 National Health And Nutrition Examination Survey (NHANES), 32\% of children age 2-19 years are overweight or obese with the percentage of these children measuring as obese at nearly $17 \%^{2,17}$. For children within this age bracket, obesity is defined as being at or above the $95^{\text {th }}$ percentile on the BMI-for-age growth chart provided by the Centers for Disease

Control (CDC) ${ }^{18,19}$. Examining the data by smaller age groups of 2-5 years, 6-11 years, and $12-19$ years, a steady increase in obesity from $8.9 \%$ to $17.5 \%$ to $20.5 \%$ respectively, can be observed ${ }^{17}$. 
Childhood obesity has been linked to a high prevalence of metabolic syndrome among children, that rises with increased obesity ${ }^{20}$. Additionally, childhood obesity increases the risk for obesity in adulthood which increases the likelihood of acquiring obesity-related diseases such as type 2 diabetes or heart disease later in life ${ }^{21,22}$. According to the CDC, $25 \%$ of deaths in the United States (US) are represented by heart disease, making it the leading cause of death ${ }^{23}$. In 2014, the CDC reported 21 million people in the US had been diagnosed with type 2 diabetes ${ }^{24}$. The NHANES reported $36.5 \%$ of adults are obese with the estimated annual medical cost associated with obesity at 147 billion dollars ${ }^{25}$.

\section{Importance of FV Consumption}

FV are high-fiber, nutrient-dense foods that are not energy-dense. Increasing consumption of FV can help reduce obesity ${ }^{26}$. Furthermore, children who have healthy dietary habits, such as eating a diet high in FV, have a higher likelihood of maintaining these healthy habits into adulthood and a decreased risk for excess weight gain when transitioning from adolescence into adulthood ${ }^{27}$. Epidemiologic studies have shown a positive association between increased FV intake and a decrease in the long-term risk of obesity ${ }^{28}$.

Unfortunately, children in the US are not meeting the recommended dietary intakes for $\mathrm{FV}^{1}$. Males age 9 to 13 years are consuming an average of 1.1 cups of vegetables per day compared to the recommended 2 to 3 cups per day, and an average of 1.1 cups of fruit per day compared to the recommended 1.5 to 2 cups per day ${ }^{1}$. Females age 9 to 13 years are consuming an average of 1 cup of vegetables per day compared to the 
recommended 1.5 to 3 cups per day, and an average of 1.1 cups of fruit per day compared to the recommended 1.5 to 2 cups per day ${ }^{1}$.

\section{Impact of the Nutrition Environment}

A child's nutrition environment plays a significant role in the types of foods they choose to eat, and therefore can significantly influence the amount of FV they consume $^{29}$. A nutrition environment is any place in the community where food is purchased and eaten ${ }^{29}$. Many low-income students consume the majority of their meals at school, participating in both the School Breakfast Program and the National School Lunch Program (NSLP) ${ }^{30,31}$. In an effort to increase FV consumption, the NSLP has established specific guidelines regarding the amount of FV that are served each day during school lunch (a minimum of .5 cups of fruit and .75 cups of vegetables per day) ${ }^{32,33}$. Specific types of foods and their preparation method, however, are left up to the discretion of the local school food authorities ${ }^{32}$.

Simple changes in the presentation and promotion of healthy foods in any nutrition environment can have a significant impact on healthy choices made by consumers ${ }^{34}$. Wansink's research shows that the CAN (Convenient, Attractive, Normal) approach, aimed at making healthy foods the most Convenient, Attractive, Normal choice, is an effective strategy for change ${ }^{34}$. Making healthy foods more Convenient to see or select can be achieved by changing the location where the food is displayed or including healthy foods in pre-packaged meals/value meals ${ }^{34}$. Healthy foods can seem like a more Attractive choice if the way they are displayed or if the name is

changed to be more appealing to consumers ${ }^{34}$. Finally, the power of suggestion can 
make the healthy choice seem more Normal, i.e. placing a vegetable sticker in one section of a child's lunch tray, suggesting that vegetables belong there ${ }^{34}$.

The Smarter Lunchroom Movement is an initiative that was designed to achieve these CAN types of environmental changes in school lunchrooms ${ }^{35,36}$. Smarter Lunchroom techniques are simple, low-cost changes which can easily transform the school lunchroom into an environment that promotes healthy choices ${ }^{36}$. Changes include displaying whole fruits in attractive bowls or baskets instead of metal chaffing dishes, moving FV to a more prominent place in the lunch line, and giving vegetables fun, descriptive names ${ }^{35}$. Results show at least a $20 \%$ increase in FV sales in school lunchrooms after implementing these techniques ${ }^{37,38}$.

\section{Nutrition Education Interventions}

\section{Impact of Increased Nutrition Knowledge}

Nutrition education can increase a child's nutrition knowledge, and an increase in nutrition knowledge can lead to healthier food choices ${ }^{15,39,40}$. The 2012 School Health Policies and Practices Study reported that $82.1 \%$ of school districts in the US required teaching about nutrition and dietary behavior in elementary schools, but only $62.9 \%$ of school districts provide funding for professional development or offer professional development to health education teachers on nutrition and dietary behavior $^{41}$. These statistics suggest a need for low-cost nutrition education interventions that can be incorporated into the existing curriculum.

"Smart Bodies" is a wellness program designed to increase nutrition knowledge and self-efficacy among elementary school students ${ }^{15}$. Tuuri et al. conducted a 
randomized controlled intervention using this program at 14 low-income elementary schools in Louisiana to determine increases in nutrition knowledge, increased selfefficacy to choose a healthy food over an unhealthy food, and FV preferences ${ }^{15}$. There were over 500 participants including both intervention and control schools ${ }^{15}$. The program included interactive assemblies, videos, lessons and games incorporating the OrganWise Guys ${ }^{\mathrm{TM}}$, characters designed to make children aware of the different parts of their bodies and how to keep them healthy ${ }^{15}$. The program was designed for teachers to incorporate into their existing lessons and were supported by their local university cooperative extension ${ }^{15}$. Changes in nutrition knowledge and self-efficacy were measured pre- and post-intervention using an assessment designed specifically for this program which was validated during the pilot study ${ }^{15}$. At the end of the $12-$ week intervention, participants in the intervention group showed a greater increase in nutrition knowledge compared to the control group $\left(F_{(1,553)}=6.99, \mathrm{p}=0.00\right)^{15}$. Participants in the intervention group also showed a greater increase in self-efficacy than the control group $\left(F_{(1,404)}=8.38, \mathrm{p}=0.00\right)$, but no significant difference in $\mathrm{FV}$ preferences ${ }^{15}$.

\section{Impact of Nutrition Education on Attitudes Towards FV}

A recent study examining children's attitudes towards healthy eating concluded children do not view choosing healthy foods as an important factor in their dietary intake, posing a risk to an increase in childhood obesity rates ${ }^{42}$. Nutrition education interventions, however, may have a positive influence on children's attitudes towards $\mathrm{FV}^{8,9}$. 
Healthy Buddies, a health promotion program conducted in British Columbia elementary schools, partnered younger students (grades kindergarten to 3) with older students (grades 4 to 7 ) as healthy-living mentors ${ }^{43}$. Each week older students were responsible for teaching 30-minute health lessons to the younger students after receiving the same lessons from intervention teachers for a total of 21 lessons ${ }^{43}$. The program objective was to determine the impact of Healthy Buddies by measuring changes in healthy living knowledge, behaviors, habits and attitudes ${ }^{43}$. Knowledge, behaviors, and habits were measured using questionnaires adapted from other previously validated questionnaires ${ }^{43}$. The knowledge questionnaire asked questions about the nutritional value of specific foods, and benefits of specific physical activities, with a maximum possible score of $76^{43}$. The behavior questionnaire asked questions about the frequency specific foods and beverages were consumed, and the frequency of which specific physical activities are performed, with a maximum possible score of $88^{43}$. The habit questionnaire asked questions about the amount of time spent on specific lifestyle habits (such as eating when bored), with a maximum possible score of $68^{43}$. Attitudes were measured using questions from the Child Eating Attitudes Test which is used to diagnose eating disorders in children ${ }^{43}$. Results showed significant increases in the intervention group for all four measures: intervention group knowledge scores for Kindergarten - Grade 3 increased by 4.1 points $(\mathrm{p}<0.001)$ and Grades $4-7$ increased by 7.1 points $(\mathrm{p}<0.001)$; intervention group behavior scores for Kindergarten - Grade 3 increased by 3.2 points $(\mathrm{p}<0.001)$; intervention group habit scores for Kindergarten - Grade 3 increased by 2.3 points $(\mathrm{p}<0.001)$ and Grades $4-7$ increased by 1.7 points $(\mathrm{p}<0.001)$; attitudes improved 
significantly in intervention schools $(\mathrm{p}<0.002)^{43}$. These results indicate that nutrition knowledge has a positive impact on behaviors, habits and attitudes towards healthy foods ${ }^{43}$.

\section{Impact of Nutrition Education on FV Consumption}

Increasing nutrition knowledge is an important first step in helping children make healthier choices. Many studies go beyond looking at just an increase in knowledge or the ability to make a healthier choice, and measure changes in consumption of healthy foods $5,7,9,16,39,44-52$. Often these studies look specifically at changes in FV consumption. A review of schools who participate in the Fresh Fruit and Vegetable Program (FFVP) indicated that these schools offer more FV and intake of FV is higher among students in these schools than schools who do not participate in the program ${ }^{53}$.

The FFVP, federally funded by the United States Department of Agriculture, is offered by more than $25 \%$ of elementary schools in the US ${ }^{47,54}$. The program is designed to provide an additional serving of FV to children in low-income elementary schools as a snack independent from school breakfast or lunch ${ }^{47,54}$. An evaluation estimating the effect of the FFVP showed that students in schools who participate in the FFVP increased FV intake by approximately one third of a cup $(0.32$ cups per day; $\mathrm{p}<0.001)$ more than students at schools who did not participate in the FFVP ${ }^{54}$. Greene et al. conducted a study of 3 low-income, urban elementary schools showing that the addition of an education component to the FFVP is even more beneficial in increasing $\mathrm{FV}$ consumption ${ }^{16}$. In this study, one school received an education component along with the FFVP, one school received only the FFVP, and one school 
did not receive the FFVP or the education component ${ }^{16}$. The students who received both the education component and the FFVP had a significant average increase in consumption of fruit of $0.89 \pm 1.75$ pieces per day $(\mathrm{F}=8.4, \mathrm{p}<.001)$ and vegetables of $0.81 \pm 1.8$ times per day $(\mathrm{F}=4.6, \mathrm{p}=.01)$, while students at the other 2 schools had no significant change in FV consumption ${ }^{16}$.

Struempler et al. found that a nutrition education intervention with elementary school students in Alabama who participated in the FFVP was also successful at increasing FV consumption ${ }^{5}$. Students were randomly assigned to treatment $(n=1,674)$ and control $(n=803)$ groups ${ }^{5}$. The treatment group participated in nutrition classes once a week for 17 weeks and also received a FV tasting each week ${ }^{5}$. Changes in FV consumption were measured using a checklist designed specifically for this study where each day at school students self-reported the number of servings of FV they consumed during school lunch ${ }^{5}$. Results indicated treatment schools significantly increased fruit consumption by 0.35 weekly servings $(\mathrm{p}<0.001)$ and vegetable consumption by 0.66 weekly servings $(\mathrm{p}<0.001)$ from pre-intervention to postintervention ${ }^{5}$. FV consumption was measured weekly and showed an increase each week up to week 10 at which point it became stable ${ }^{5}$.

These two studies demonstrate the importance of nutrition education, but they also help to illustrate the benefit of supplementing these programs with the opportunity for children to try FV at the same time. In a similar nutrition education intervention, Nguyen et al. found a significant increase $(\mathrm{p}=.001)$ in nutrition knowledge from baseline to post-intervention, but no significant change in FV consumption ${ }^{39}$. This program included weekly 45 minute lessons covering various topics about healthy 
eating and were delivered for a period of 3 months ${ }^{39}$. The difference between this program and the programs discussed previously is that no FV were offered in conjunction with these lessons. Nguyen et al. concluded that environmental changes, including offering FV at school, are key to significant behavior change ${ }^{39}$.

A 2013 position paper from the Academy of Nutrition and Dietetics, provided a comprehensive review of Interventions for the Prevention and Treatment of Pediatric Overweight and Obesity, school-based nutrition education interventions were found to be more effective when paired with other components such as physical activity and supplemented with FV offerings ${ }^{9}$. Furthermore, the paper indicates that school-based nutrition interventions in general are most successful when they include policy change, input from multiple parties (students, parents, school staff), and environmental change ${ }^{9}$.

\section{PSE Interventions}

Policy, Systems and Environmental (PSE) interventions use these three avenues (PSE) to drive change. This model is commonly used in community interventions with a fair amount of success ${ }^{55,56}$. In 2010, 50 communities across the U.S. received Communities Putting Prevention to Work grants from the CDC to implement PSE interventions ${ }^{55}$. Community teams developed strategies to improve health over a 2 -

year period in the following categories: nutrition, physical activity, and tobacco use ${ }^{55}$. Progress was assessed at 12 months at which point community teams on average reached $43 \%$ of the targeted population ${ }^{55}$. 
One PSE intervention associated with the grant in low-income school districts of King County, Washington focused on obesity prevention among high school students ${ }^{14}$. This intervention included student-led promotions of healthy eating campaigns, farm to school initiatives, nutrition training for school cafeteria staff, and participation in community health coalitions from 2010-2012 ${ }^{14}$. Students in King County school districts who received the intervention were compared with students in low-income school districts in other counties who did not receive any intervention using logistic regression analysis ${ }^{14}$. There was a significant decrease $(p=.02)$ in obesity in King County students compared to students in other school districts ${ }^{14}$.

School-based nutrition interventions have started to incorporate Policy, Systems and Environmental (PSE) approaches at the elementary school level, which present a different dynamic than middle school or high school, and will be the focus of this review. PSE interventions can empower children to be involved in changes that impact them directly, making them more likely to incorporate these changes into their daily routines ${ }^{9,12}$. A 2012 review of studies on student involvement suggests that empowering students by involving them in the decision making process has a strong positive effect on their self-esteem and ability to drive change ${ }^{57}$. Empowerment gives children a voice and can include involvement in activities such as learning constructive ways to participate in Wellness Committee meetings, or making suggestions for ways to improve the school cafeteria environment ${ }^{9,12}$.

The Shaping Healthy Choices Program is a PSE intervention designed for fourth grade students in California elementary schools ${ }^{7,58}$. The main objectives of the program were to increase nutrition knowledge, increase FV intake, increase vegetable 
preference, and improve BMI percentiles ${ }^{7,58}$. The intervention involved implementation of school gardens; participation of family, community and wellness committee members; local produce featured in school lunchrooms; cooking demonstrations; and 15 1-hour nutrition education lessons being taught in the classrooms by a trained nutrition educator ${ }^{7,58}$. Nutrition knowledge was measured using a validated nutrition questionnaire customized specifically for this intervention; FV intake was assessed using The Block Food Frequency Questionnaire; vegetable preference was assessed using a previously validated vegetable preference assessment; and height, weight and waist circumference measurements were collected using guidelines published by the Center for Disease Control and Prevention ${ }^{7,58}$. Results showed that students in the intervention schools had significant improvement in BMI percentiles $(-6.08 ; \mathrm{p}<.01)$, BMI Z-scores $(-.28 ; \mathrm{p}<.001)$, and waist to height ratio (-.02; $\mathrm{p}<.001)^{7}$. There was also a significant increase in nutrition knowledge when compared to the control schools $(\mathrm{p}<.001)$, but there were no significant changes in FV intake or vegetable preference ${ }^{7}$.

The Healthy Options for Nutrition Environments in Schools (Healthy ONES) study is a randomized group trial that looked to involve school staff, parents and children in policy and environmental changes that would make the school cafeteria a healthier eating environment and would encourage children to make healthier choices ${ }^{4}$. Children were observed monthly using an observation system designed and tested specifically for this study during school meals over a period of 2 years to determine the amount of unhealthy food and beverage items that were brought in from the outside ${ }^{4}$. Additionally, to determine change in obesity rates, student's BMI were 
measured at three time points ${ }^{4}$. Results indicated significant change in that intervention schools showed a decrease in outside unhealthy food items over time $(\mathrm{p}=.005)$, while control schools showed an increase in outside unhealthy food items over time $(p=.04)$, but no significant changes in BMI were observed ${ }^{4}$.

Sallis, et al. conducted a randomized control trial of a school-based nutrition intervention ${ }^{10}$. The objective was to decrease the amount of fat students were consuming while increasing physical activity through policy and environmental change ${ }^{10}$. School staff, parents and students were all involved in implementing policy and environmental changes which included working with food services to offer more low-fat options in the school lunchroom, as well as making changes to the physical education curriculum ${ }^{10}$. Changes in physical activity were observed using two separate validated methods, Systems for Observing Fitness Instruction Time and Systems for Observing Play and Leisure Activity of Youth ${ }^{10}$. Amount of fat consumed at school lunch was measured by documenting meals provided by food service and analyzing fat content using Nutrition Data Systems, and also collecting

nutrition facts labels from students who brought a bag lunch from home ${ }^{10}$. While there was no significant decrease in the amount of fat consumed, there was a significant increase $(\mathrm{p}<0.009)$ in physical activity ${ }^{10}$.

\section{Assessment with Children}

It is important to note the challenges associated with conducting dietary assessments with students. Some common instruments used to assess dietary intake are 24-hour food recalls, dietary records, dietary histories, Food Frequency Questionnaires, and 
observations of children's diets ${ }^{59}$. All of these methods can be complicated by a child's cognitive ability, surrogate reporting, or social desirability ${ }^{59}$. Children under the age of 12 have a limited attention span, and possess a limited ability to recall dietary intake unless it is in the immediate past ${ }^{59,60}$. Additionally, they often have a difficult time comprehending assessment questions and require a great deal of guidance, especially considering their limited knowledge of food preparation, measurement, and ability to estimate portion sizes ${ }^{59,60}$. Some types of reporting, such as dietary records, can be completed by parents or caregivers providing information for the child ${ }^{59}$. However, child self-reports are less accurate because children also have a tendency to respond with the most socially desirable answer, which results in under- or over-reporting ${ }^{59}$. Studies will often cite these challenges as limitations to achieving desired outcomes ${ }^{5,7}$. Furthermore, when conducting assessments in predominantly low-income school districts, it is important to consider that children of low socioeconomic status generally perform at a lower academic level than children of higher socioeconomic status ${ }^{61}$. According to national test scores, an additional academic disparity exists by ethnicity with Whites averaging higher test scores than Blacks and Hispanics in math and reading ${ }^{62}$.

\section{Conclusion}

Childhood obesity is a large-scale problem with nearly one-third of children in the US being classified as overweight or obese ${ }^{2,17}$. Children who are obese are more likely to be obese as adults and therefore have a higher risk for acquiring obesity related diseases later in life ${ }^{21,22}$. Increasing FV intake can help combat this obesity epidemic 28. 
Nutrition interventions have proved to be an effective means of increasing FV intake 5,9,16,45. This review found that the most effective nutrition interventions have multiple components, combining nutrition education with physical activity, the opportunity to try FV, policy change, community involvement, and empowering children to be involved in the decision making process $4,7,9,10,57,58$. 


\section{Bibliography}

1. A Closer Look at Current Intakes and Recommended Shifts - 2015-2020 Dietary Guidelines - health.gov. http://health.gov/dietaryguidelines/2015/guidelines/chapter-2/a-closer-look-atcurrent-intakes-and-recommended-shifts/\#subnav-4. Accessed May 23, 2016.

2. Ogden CL, Carroll MD, Kit BK, Flegal KM. Prevalence of childhood and adult obesity in the United States, 2011-2012. JAMA. 2014;311(8):806-814. doi:10.1001/jama.2014.732.

3. Perry CL, Lytle LA, Feldman H, et al. Effects of the Child and Adolescent Trial for Cardiovascular Health $(\mathrm{CATCH})$ on Fruit and Vegetable Intake. $J$ Nutr Educ. 1998;30(6):354-360. doi:10.1016/S0022-3182(98)70357-7.

4. Coleman KJ, Shordon M, Caparosa SL, Pomichowski ME, Dzewaltowski DA. The healthy options for nutrition environments in schools (Healthy ONES) group randomized trial: using implementation models to change nutrition policy and environments in low income schools. Int J Behav Nutr Phys Act. 2012;9:80. doi:10.1186/1479-5868-9-80.

5. Struempler BJ, Parmer SM, Mastropietro LM, Arsiwalla D, Bubb RR. Changes in fruit and vegetable consumption of third-grade students in body quest: food of the warrior, a 17-class childhood obesity prevention program. J Nutr Educ Behav. 2014;46(4):286-292. doi:10.1016/j.jneb.2014.03.001.

6. Olsho LEW, Klerman JA, Ritchie L, Wakimoto P, Webb KL, Bartlett S. Increasing Child Fruit and Vegetable Intake: Findings from the US Department of Agriculture Fresh Fruit and Vegetable Program. J Acad Nutr Diet. 2015;115(8):1283-1290. doi:10.1016/j.jand.2014.12.026.

7. Scherr RE, Linnell JD, Dharmar M, et al. A Multicomponent, School-Based Intervention, the Shaping Healthy Choices Program, Improves NutritionRelated Outcomes. J Nutr Educ Behav. 2017. doi:10.1016/j.jneb.2016.12.007.

8. Campbell AC, Barnum D, Ryden V, Ishkanian S, Stock S, Chanoine J-P. The Effectiveness of the Implementation of Healthy Buddies ${ }^{\mathrm{TM}}$, a School-Based, Peer-Led Health Promotion Program in Elementary Schools. Can J Diabetes. 2012;36(4):181-186.e2. doi:10.1016/j.jcjd.2012.07.001.

9. Hoelscher DM, Kirk S, Ritchie L, Cunningham-Sabo L. Position of the Academy of Nutrition and Dietetics: Interventions for the Prevention and Treatment of Pediatric Overweight and Obesity. J Acad Nutr Diet. 2013;113(10):1375-1394. doi:10.1016/j.jand.2013.08.004.

10. Sallis JF, McKenzie TL, Conway TL, et al. Environmental interventions for eating and physical activity. Am J Prev Med. 2003;24(3):209-217. doi:10.1016/S0749-3797(02)00646-3.

11. Kubik MY, Lytle LA, Hannan PJ, Perry CL, Story M. The association of the school food environment with dietary behaviors of young adolescents. Am J Public Health. 2003;93(7):1168-1173. /pmc/articles/PMC1447928/?report=abstract. Accessed August 19, 2016.

12. Story M, Nanney MS, Schwartz MB. Schools and obesity prevention: creating school environments and policies to promote healthy eating and physical activity. Milbank Q. 2009;87(1):71-100. doi:10.1111/j.1468- 
0009.2009.00548.x.

13. Cradock AL, McHugh A, Mont-Ferguson H, et al. Effect of school district policy change on consumption of sugar-sweetened beverages among high school students, Boston, Massachusetts, 2004-2006. Prev Chronic Dis.

2011;8(4):A74.

http://www.pubmedcentral.nih.gov/articlerender.fcgi artid=3136975\&tool=pmc entrez\&rendertype=abstract. Accessed May 13, 2016.

14. Kern E, Chan NL, Fleming DW, Krieger JW. Declines in student obesity prevalence associated with a prevention initiative - King County, Washington, 2012. MMWR Morb Mortal Wkly Rep. 2014;63(7):155-157. http://www.ncbi.nlm.nih.gov/pubmed/24553199. Accessed May 10, 2016.

15. Tuuri G, Zanovec M, Silverman L, et al. "Smart Bodies" school wellness program increased children's knowledge of healthy nutrition practices and selfefficacy to consume fruit and vegetables. Appetite. 2009;52(2):445-451. doi:10.1016/j.appet.2008.12.007.

16. Greene GW, Fallon PR, Paolino PP, Sebelia L. Impact of Adding a Nutrition Education Component to the United States Department of Agriculture Fresh Fruit and Vegetable Program on Fruit and Vegetable Consumption in 3rd and 4th Grade Students in an Urban School District. J Acad Nutr Diet. 2015;115(9):A49. doi:10.1016/j.jand.2015.06.170.

17. Childhood Obesity Facts |Child | Data | Obesity |DNPAO | CDC. http://www.cdc.gov/obesity/data/childhood.html. Accessed February 11, 2016.

18. Ogden CL, Carroll MD, Kit BK, Flegal KM. Prevalence of obesity and trends in body mass index among US children and adolescents, 1999-2010. JAMA. 2012;307(5):483-490. doi:10.1001/jama.2012.40.

19. Kuczmarski RJ, Ogden CL, Grummer-Strawn LM, et al. CDC growth charts: United States. Adv Data. 2000;(314):1-27. http://www.ncbi.nlm.nih.gov/pubmed/11183293. Accessed January 12, 2017.

20. Weiss R, Dziura J, Burgert TS, et al. Obesity and the metabolic syndrome in children and adolescents. N Engl J Med. 2004;350(23):2362-2374.

doi:10.1056/NEJMoa031049.

21. Torpy JM, Campbell A, Glass RM. JAMA patient page. Chronic diseases of children. JAMA. 2010;303(7):682. doi:10.1001/jama.303.7.682.

22. Park MH, Falconer C, Viner RM, Kinra S. The impact of childhood obesity on morbidity and mortality in adulthood: a systematic review. Obes Rev. 2012;13(11):985-1000. doi:10.1111/j.1467-789X.2012.01015.x.

23. Heart Disease Awareness|Diseases|Resources|Genomics|CDC. https://www.cdc.gov/genomics/resources/diseases/heart.htm. Accessed January 14, 2017.

24. 2014 Statistics Report | Data \& Statistics | Diabetes |CDC. https://www.cdc.gov/diabetes/data/statistics/2014StatisticsReport.html. Accessed January 14, 2017.

25. Adult Obesity Facts | Overweight \& Obesity | CDC. https://www.cdc.gov/obesity/data/adult.html. Accessed January 14, 2017.

26. Rolls BJ, Ello-Martin JA, Tohill BC. What Can Intervention Studies Tell Us about the Relationship between Fruit and Vegetable Consumption and Weight 
Management? Nutr Rev. 2004;62(1):1-17. doi:10.1111/j.1753-

4887.2004.tb00001.x.

27. Hu T, Jacobs DR, Larson NI, Cutler GJ, Laska MN, Neumark-Sztainer D.

Higher Diet Quality in Adolescence and Dietary Improvements Are Related to Less Weight Gain During the Transition From Adolescence to Adulthood. $J$ Pediatr. 2016;178:188-193.e3. doi:10.1016/j.jpeds.2016.08.026.

28. Ledoux TA, Hingle MD, Baranowski T. Relationship of fruit and vegetable intake with adiposity: a systematic review. Obes Rev. 2011;12(5):e143-50. doi:10.1111/j.1467-789X.2010.00786.x.

29. About NEMS. http://www.med.upenn.edu/nems/about.shtml. Accessed March 22, 2016.

30. SBPfactsheet.pdf. http://www.fns.usda.gov/sites/default/files/sbp/SBPfactsheet.pdf. Accessed May 23, 2016.

31. NSLPFactSheet.pdf. http://www.fns.usda.gov/sites/default/files/NSLPFactSheet.pdf. Accessed May 23, 2016.

32. National School Lunch Program (NSLP) | Food and Nutrition Service. http://www.fns.usda.gov/nslp/national-school-lunch-program-nslp. Accessed January 12, 2016.

33. 7cfr210_13_1.pdf. http://www.fns.usda.gov/sites/default/files/7cfr210_13_1.pdf. Accessed July $15,2016$.

34. Wansink B. Change Their Choice! Changing Behavior Using the CAN Approach and Activism Research. Psychol Mark. 2015;32(5):486-500. doi:10.1002/mar.20794.

35. Our Ideas $\mid$ Smarter Lunchrooms Movement. http://smarterlunchrooms.org/ideas. Accessed March 22, 2016.

36. Wansink B, Smith LE, Just DR. Cornell's Smarter Lunchroom Initiative: Engineering Smart Selections. J Nutr Educ Behav. 2010;42(4):S75. doi:10.1016/j.jneb.2010.03.017.

37. Wansink B, Just D, Smith L. What Is in a Name? Giving Descriptive Names to Vegetables Increases Lunchroom Sales. J Nutr Educ Behav. 2011;43(4):S1. doi:10.1016/j.jneb.2011.03.014.

38. Wansink B, Just D, Smith L. Move the Fruit: Putting Fruit in New Bowls and New Places Doubles Lunchroom Sales. J Nutr Educ Behav. 2011;43(4):S1. doi:10.1016/j.jneb.2011.03.013.

39. Nguyen B, Murimi M, Rana Z, Lee H, Halloran R. Impact of a Nutrition Education Intervention on Nutrition Knowledge and Dietary Intake of Fruits, Vegetables, and Milk Among Fourth and Fifth-Grade Elementary School Children. J Nutr Educ Behav. 2016;48(7):S79. doi:10.1016/j.jneb.2016.04.211.

40. Watts SO, Piñero DJ, Alter MM, Lancaster KJ. An Assessment of nutrition education in selected counties in New York State elementary schools (kindergarten through fifth grade). J Nutr Educ Behav. 2012;44(6):474-480. doi:10.1016/j.jneb.2012.01.010.

41. FS_Nutrition_SHPPS2012.pdf. 
https://www.cdc.gov/healthyyouth/shpps/2012/factsheets/pdf/FS_Nutrition_SH PPS2012.pdf. Accessed January 28, 2017.

42. Roman I. The Psychology of Nutritional Behaviour and Children's Nutrition Education. Procedia - Soc Behav Sci. 2014;149:819-824.

doi:10.1016/j.sbspro.2014.08.327.

43. Campbell AC, Barnum D, Ryden V, Ishkanian S, Stock S, Chanoine J-P. The Effectiveness of the Implementation of Healthy Buddies ${ }^{\mathrm{TM}}$, a School-Based, Peer-Led Health Promotion Program in Elementary Schools. Can J Diabetes. 2012;36(4):181-186.e2. doi:10.1016/j.jcjd.2012.07.001.

44. Ritchie LD, Wakimoto P, Woodward-Lopez G, et al. The Healthy Communities Study Nutrition Assessments: Child Diet and the School Nutrition

Environment. Am J Prev Med. 2015;49(4):647-652.

doi:10.1016/j.amepre.2015.06.016.

45. Havas S, Heimendinger J, Damron D, et al. 5 A Day for better health--nine community research projects to increase fruit and vegetable consumption.

Public Health Rep. 1995;110(1):68-79.

http://www.ncbi.nlm.nih.gov/pubmed/7838947. Accessed February 25, 2017.

46. Blom-Hoffman J. School-based promotion of fruit and vegetable consumption in multiculturally diverse, urban schools. Psychol Sch. 2008;45(1):16-27. doi:10.1002/pits.20275.

47. Olsho LEW, Klerman JA, Ritchie L, Wakimoto P, Webb KL, Bartlett S. Increasing Child Fruit and Vegetable Intake: Findings from the US Department of Agriculture Fresh Fruit and Vegetable Program. J Acad Nutr Diet. 2015;115(8):1283-1290. doi:10.1016/j.jand.2014.12.026.

48. Delgado-Noguera M, Tort S, Martínez-Zapata MJ, Bonfill X. Primary school interventions to promote fruit and vegetable consumption: a systematic review and meta-analysis. Prev Med. 2011;53(1-2):3-9.

doi:10.1016/j.ypmed.2011.04.016.

49. Horne PJ, Tapper K, Lowe CF, Hardman CA, Jackson MC, Woolner J. Increasing children's fruit and vegetable consumption: a peer-modelling and rewards-based intervention. Eur J Clin Nutr. 2004;58(12):1649-1660. doi:10.1038/sj.ejcn.1602024.

50. Song H-J, Grutzmacher S, Munger AL. Project ReFresh: Testing the Efficacy of a School-Based Classroom and Cafeteria Intervention in Elementary School Children. J Sch Health. 2016;86(7):543-551. doi:10.1111/josh.12404.

51. Ransley JK, Taylor EF, Radwan Y, Kitchen MS, Greenwood DC, Cade JE. Does nutrition education in primary schools make a difference to children's fruit and vegetable consumption? Public Health Nutr. 2010;13(11):1898-1904. doi:10.1017/S1368980010000595.

52. Anderson AS, Porteous LEG, Foster E, et al. The impact of a school-based nutrition education intervention on dietary intake and cognitive and attitudinal variables relating to fruits and vegetables. Public Health Nutr. 2005;8(6):650656. http://www.ncbi.nlm.nih.gov/pubmed/16236195. Accessed August 19, 2016.

53. Ohri-Vachaspati P, Turner L, Chaloupka FJ. Fresh Fruit and Vegetable Program participation in elementary schools in the United States and availability of fruits 
and vegetables in school lunch meals. J Acad Nutr Diet. 2012;112(6):921-926. doi:10.1016/j.jand.2012.02.025.

54. Gates G, Jackson S, Hildebrand D. Fresh Fruit \& Vegetable Program Participation in Elementary School Influences Fruit and Vegetable Selection in Middle School. J Nutr Educ Behav. 2013;45(4):S30-S31. doi:10.1016/j.jneb.2013.04.083.

55. Bunnell R, O'Neil D, Soler R, et al. Fifty communities putting prevention to work: accelerating chronic disease prevention through policy, systems and environmental change. J Community Health. 2012;37(5):1081-1090. doi:10.1007/s10900-012-9542-3.

56. Boles M, Adams A, Gredler A, Manhas S. Ability of a mass media campaign to influence knowledge, attitudes, and behaviors about sugary drinks and obesity. Prev Med. 2014;67 Suppl 1:S40-5. doi:10.1016/j.ypmed.2014.07.023.

57. Mager U, Nowak P. Effects of student participation in decision making at school. A systematic review and synthesis of empirical research. Educ Res Rev. 2012;7(1):38-61. doi:10.1016/j.edurev.2011.11.001.

58. Scherr RE, Linnell JD, Smith MH, et al. The Shaping Healthy Choices Program: Design and Implementation Methodologies for a Multicomponent, School-Based Nutrition Education Intervention. J Nutr Educ Behav. 2014;46(6):e13-e21. doi:10.1016/j.jneb.2014.08.010.

59. Pérez-Rodrigo C, Artiach Escauriaza B, Artiach Escauriaza J, Polanco Allúe I. Dietary assessment in children and adolescents: issues and recommendations. Nutr Hosp. 2015;31 Suppl 3:76-83. doi:10.3305/nh.2015.31.sup3.8755.

60. Livingstone MBE, Robson PJ, Wallace JMW. Issues in dietary intake assessment of children and adolescents. Br J Nutr. 2004;92(S2):S213. doi:10.1079/BJN20041169.

61. von Stumm S. Socioeconomic status amplifies the achievement gap throughout compulsory education independent of intelligence. Intelligence. 2017;60:57-62. doi:10.1016/j.intell.2016.11.006.

62. Rampey BD, Dion GS, Donahue PL. The Nation's Report Card: 2008 Trends in Academic Progress: Executive Summary. US Department of Education, Office of Educational Research and Improvement, National Center for Education Statistics, Washington, DC. https://nces.ed.gov/nationsreportcard/pubs/main2008/2009479.asp. Published 2009. Accessed March 10, 2017. 
B. DEMOGRPAHIC FORM

SNAP-ED - CHILD/YOUTH PARTICIPANT SURVEY FORM A-2 PLEASE PRINT

Date:

Age:

My Name Is:

First Name

Last Name

School I Attend:

Have you been to a URI SNAP-Ed workshop since October 1, 2014? $\bigcirc$ Yes $\bigcirc$ No

I am a: OBoy $\bigcirc$ Girl

I speak Spanish at home: $\bigcirc$ Yes $\bigcirc$ No $\bigcirc$ Sometimes

I am also (choose all that apply): $\bigcirc$ Asian

Black or African-American

White

American Indian or Alaskan Native

ONative Hawaiian/other Pacific Islander

OOther 


\section{Fruit and Vegetable Checklist}

These questions are about the ways you plan and fix food.

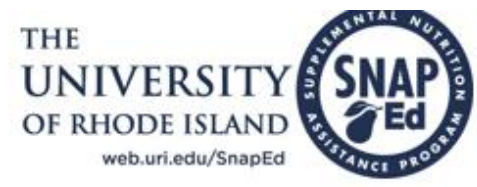

Think about how you usually do things.

Name:

Room \#:

Grade:

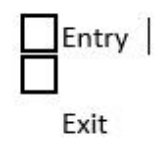

$\square$ Boy $\square$ Girl

Exit

Choose one answer for each question.

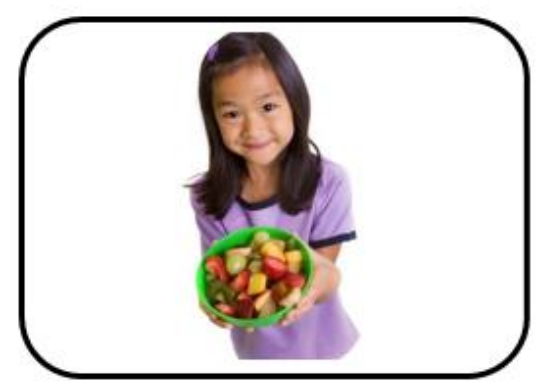

1. Do you eat fruits or vegetables as snacks?
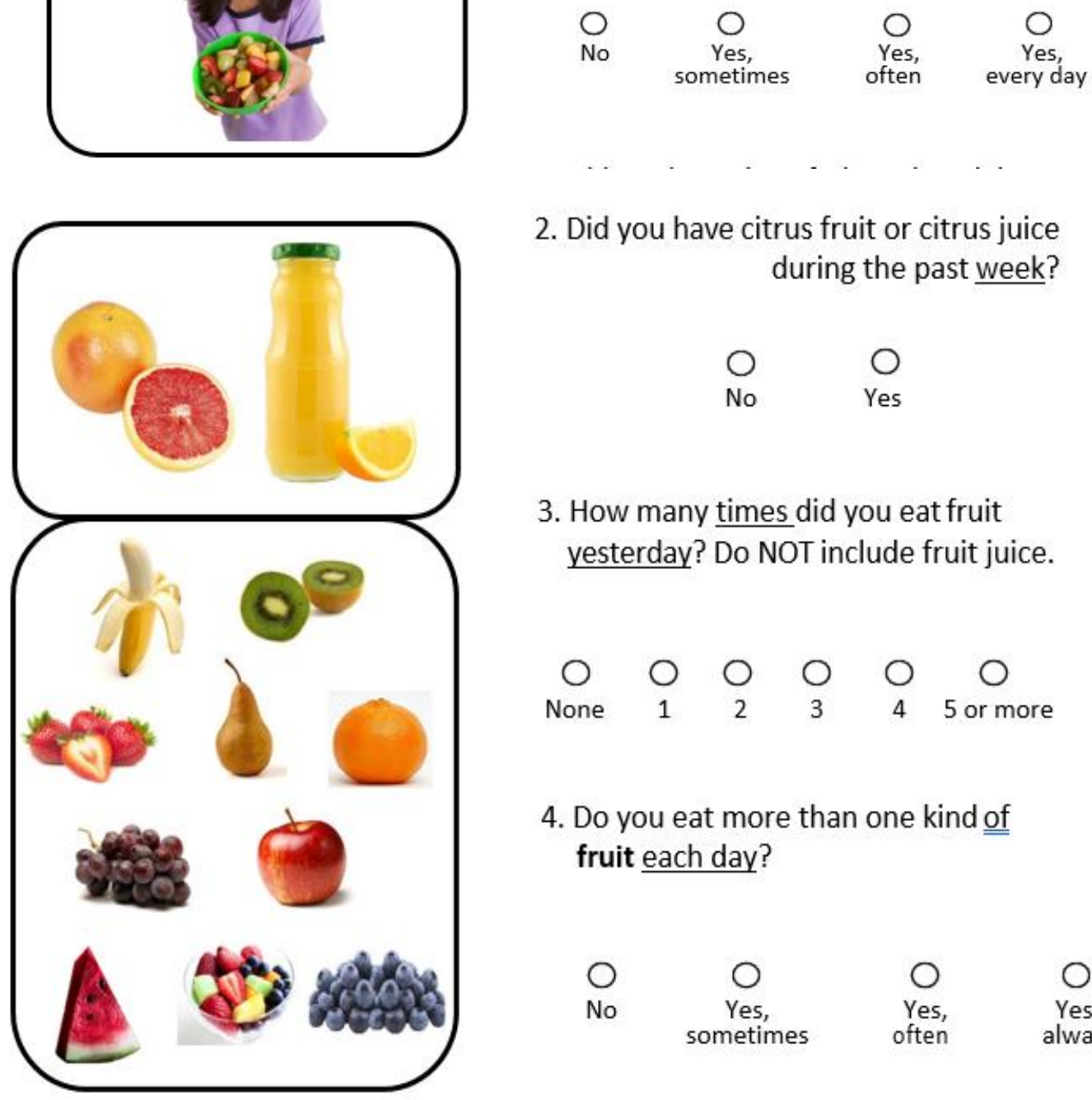

2. Did you have citrus fruit or citrus juice during the past week?

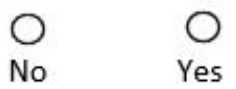

3. How many times did you eat fruit yesterday? Do NOT include fruit juice.

$\begin{array}{cccccc}\bigcirc & \bigcirc & \bigcirc & \bigcirc & \bigcirc & \bigcirc \\ \text { None } & 1 & 2 & 3 & 4 & 5 \text { or more }\end{array}$

4. Do you eat more than one kind of fruit each day?

$\begin{array}{cccc}\text { No } & \begin{array}{c}\text { Yes, } \\ \text { sometimes }\end{array} & \begin{array}{c}\text { Yes, } \\ \text { often }\end{array} & \begin{array}{c}\text { Yes, } \\ \text { always }\end{array}\end{array}$




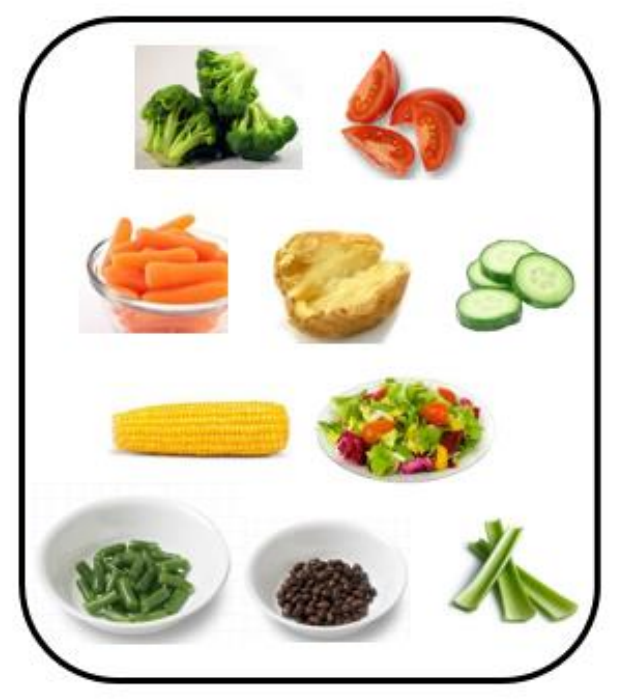

5. Do you eat more than one kind of vegetable each day?

\begin{tabular}{|c|c|c|}
\hline 0 & 0 & 0 \\
\hline No & $\begin{array}{c}\text { Yes, } \\
\text { sometimes }\end{array}$ & $\begin{array}{l}\text { Yes, } \\
\text { often }\end{array}$ \\
\hline
\end{tabular}

6. How many times did you eat vegetables yesterday?

000000 None $1 \begin{array}{lllll} & 2 & 3 & 4 & 5 \text { or more }\end{array}$

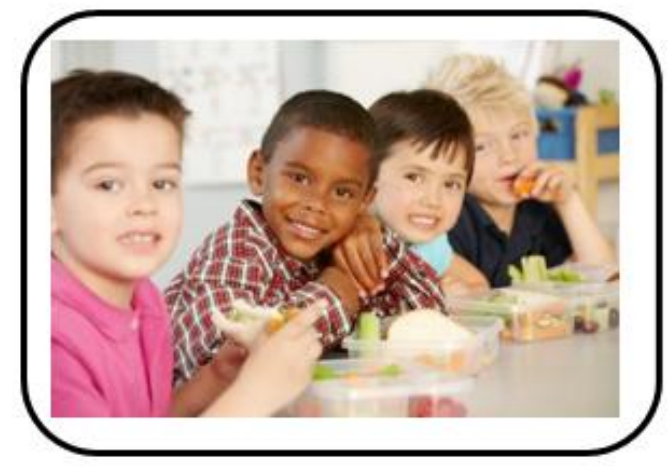

7. Do you eat 2 or more vegetables at your main meal?

No $\underset{\substack{\text { Yes, } \\ \text { sometimes }}}{\mathrm{O}}$

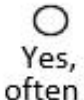
$\bigcirc$
Yes,
every day

Thank you! 


\section{KNOWLEDGE ASSESSMENT}

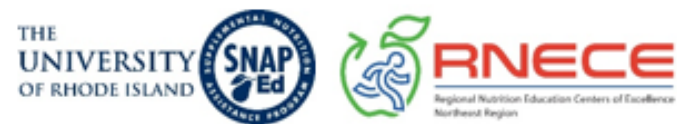

POST-KNOWLEDGE QUESTIONS

Name:

Date:

School name:

Classroom teacher's name:

Room \#:

PART 1: Directions: Circle the correct answer to complete the sentences.

1. I should eat at least fruits each day.

1

2

3

4

5

2. I should eat at least vegetables each day.

1

2

3

4

5

3. Fruits and vegetables should fill up of my plate.

none $1 / 4 \quad 1 / 2 \quad 3 / 4 \quad$ all

4. is a "go" vegetable.

onion rings

mashed potato

green beans

French fries

PART 2: Directions: Draw lines to match the color(s) with how they help your body:

red

yellow \& orange

green

purple $\&$ blue

brown, $\tan \&$ white keeps your eyes healthy and skin glowing

helps your brain learn and remember

keeps your muscles strong and body safe from germs

helps you go to the bathroom

keeps your heart strong 


\section{PART 3: Directions: Please circle the best answer for each of the following questions.}

1. An Environmental Scan is used to see how a school is.
a. Smart
b. Well behaved
c. Healthy
d. Pretty

2. What does PSE stand for?
a. Policy, Systems, and Environmental change
b. Poor School Environment
c. Public School Exchange
d. Public School Environment

3. The School Wellness Committee promotes in schools.
a. Learning
b. Healthy behaviors
c. Fun
d. Field trips

4. are catchy, short phrases that are used in advertisement.
a. Messages
b. Slogans
c. Poems
d. Posters

5. A type of message that gives information.
a. "Florida orange juice contains $75 \%$ of your daily vitamin $\mathrm{C}$ needs"
b. "Four out of five doctors recommend eating five cups of fruit and vegetables every day"
c. "Red, orange, yellow, blue, purple, green. Healthy kids eat a variety of colorful fruits every day"
d. "Eat your veggies."

6. A type of message that makes you feel good.
a. "Florida orange juice contains $75 \%$ of your daily vitamin C needs"
b. "Four out of five doctors recommend eating five cups of fruit and vegetables every day"
c. "Red, orange, yellow, blue, purple, green. Healthy kids eat a variety of colorful fruits every day"
d. "Eat your veggies."

7. A type of message that gives trust.
a. "Florida orange juice contains $75 \%$ of your daily vitamin $\mathrm{C}$ needs"
b. "Four out of five doctors recommend eating five cups of fruit and vegetables every day"
c. "Red, orange, yellow, blue, purple, green. Healthy kids eat a variety of colorful fruits every day"
d. "Eat your veggies." 
PART 4: Directions: Choose the answer that best shows how you feel.

\begin{tabular}{|c|c|c|c|c|}
\hline \# & Item & $\begin{array}{c}1 \\
\text { No }\end{array}$ & $\begin{array}{c}2 \\
\text { Maybe }\end{array}$ & $\begin{array}{c}3 \\
\text { Yes }\end{array}$ \\
\hline 8. & $\begin{array}{l}\text { I have an opinion about the fruit and vegetable choices that are served } \\
\text { in my school. }\end{array}$ & & & \\
\hline 9. & $\begin{array}{l}\text { I have an opinion about the fruit and vegetable choices that are served } \\
\text { in my home. }\end{array}$ & & & \\
\hline 10. & My school encourages me to eat more fruits and vegetables. & & & \\
\hline 11. & My family encourages me to eat more fruits and vegetables. & & & \\
\hline
\end{tabular}

Directions: Choose the answer that best shows how you feel.

\begin{tabular}{|c|l|c|c|c|c|c|c|}
\hline$\#$ & \multicolumn{1}{|c|}{ Item } & $\begin{array}{c}\text { I don't } \\
\text { eat fruits } \\
\text { and } \\
\text { vegetables }\end{array}$ & $\begin{array}{c}\text { I don't } \\
\text { like } \\
\text { them a } \\
\text { lot }\end{array}$ & $\begin{array}{c}\text { I don't } \\
\text { like } \\
\text { them } \\
\text { a little }\end{array}$ & $\begin{array}{c}\text { Not } \\
\text { Sure }\end{array}$ & $\begin{array}{c}\text { I like } \\
\text { them } \\
\text { a little }\end{array}$ & $\begin{array}{c}\text { I like } \\
\text { them } \\
\text { a lot }\end{array}$ \\
\hline 12. & $\begin{array}{l}\text { I like the fruits and vegetables that } \\
\text { are served in my school. }\end{array}$ & & & & & & \\
\hline 13. & $\begin{array}{l}\text { I like the fruits and vegetables that } \\
\text { are served in my home. }\end{array}$ & & & & & & \\
\hline
\end{tabular}

